\title{
PENINGKATAN RASIO UREA:UREASE DALAM PROSES HIDROLISIS ALKALI MENURUNKAN KOMPONEN KARBOHIDRAT STRUKTURAL PADA RUMPUT KUME (Sorghum plumosum var. Timorense) KERING
}

\author{
Twen. O. Dami Dato dan Marthen L. Mullik \\ Fakultas Peternakan Universitas Nusa Cendana \\ Jl. Adisucipto, Kupang NTT 85001 Indonesia \\ Coresponding author: martin_kpg@yahoo.com.au
}

\begin{abstract}
ABSTRAK
Kandungan karbohidrat struktural terutama lignin rumput Kume (Sorghum plumosum var. Timorense) kering relatif tinggi sehingga menurunkan nilai manfaatnya sebagai pakan. Penelitian ini bertujuan untuk menurunkan kandungan lignin, selulosa dan hemiselulosa rumput Kume dengan cara hidrolisis alkali menggunakan filtrat abu sekam padi (FASP) dan penambahan urea dan enzim urease pada rasio yang berbeda. Metode eksperimen laboratorium menggunakan rancangan acak lengkap (RAL) $6 \times$ 3 untuk menguji 6 perlakuan yakni: RK1= Rumput Kume kering dipercik FASP 15\% b/v dihidrolisis selama $3 \mathrm{jam}, \mathrm{RK} 2=\mathrm{RK} 1$ + urea $4 \%, \mathrm{RK}_{3}=\mathrm{RK} 1+$ urea $4 \%$ + urease $8 \%(1: 2), \mathrm{RK} 4=\mathrm{RK} 1+$ urea $4 \%+$ urease $12 \%(1: 3), \mathrm{RK}_{5}=\mathrm{RK} 1+$ urea $4 \%$ + urease $16 \%(1: 4)$, dan $\mathrm{RK} 6=\mathrm{RK} 1$ + urea $4 \%$ + urease 20\% (1:5). Sebagai kontrol adalah rumput Kume kering yang tidak dihidrolisis. Tiap unit percobaan digunakan $1 \mathrm{~kg}$ rumput Kume kering (basis bahan kering) sebagai substrat dan dihidrolisis dalam 1 silo kantong plastik selama 3 jam. Proses pembuatan FSAP sesuai petunjuk Dami Dato (1998). Ke dalam satu liter FASP ditambahkan 40g urea dan $10 \mathrm{~g}$ kalsium karbonat sebagai sumber kalsium, 18g garam dapur sebagai sumber natrium, dan $2 \mathrm{~g}$ belerang sebagai sumber sulfur. Prosedur hidrolisis dilakukan sesuai petunjuk Sutrisno dkk. (1986). Variabel yang diamati adalah perubahan kandungan neutral detergent fibre (NDF), hemiselulosa, selulosa, lignin, dan acid detergent fibre (ADF). Data yang diperoleh dianalisis secara statistik sesuai prosedur General linear model untuk RAL dan perbedaan antar perlakuan diuji menggunakan uji Duncan pada nilai $\alpha=0,05$. Hasil penelitian menunjukkan bahwa peningkatan rasio urea:urease dari 1:2 hingga 1:5 sangat nyata menurunkan kandungan NDF sebesar 7,87-19,49\%, hemiselulosa sebesar 31,10-65,72\%, selulosa sebesar 15,13- 31,60\%, lignin sebesar 3,97-20,16\%, dan meningkatkan kandaungan ADF sebesar 8,84-13,78\%; namun tidak ada perbedaan antara rasio 1:4 (RK5) dan 1:5 (RK6) untuk semua variabel. Disimpulkan bahwa, hidrolisis rumput Kume kering secara alkali menggunakan FASP dan ditambahi urea dan enzim urease dengan rasio 1:4 merupakan perlakuan terbaik untuk menurunkan kandungan NDF, hemiselulosa, selulosa, lignin, dan meningkatkan kandungan $\mathrm{ADF}$ dalam rumput Kume kering.
\end{abstract}

Kata kunci:

\section{PENDAHULUAN}

Rumput Kume (Sorghumplumosum var. Timorense) merupakan salah satu rumput lokal andalan bagi peternakan ruminansia di Nusa Tenggara Timur (NTT) karena pada kondisi alamah (tanpa perlakuan) produksi biomasa yang dapat mencapai 10,5 t/ha/thn, tetapi laju pertumbuhannya relatif tinggi $(1,05 \mathrm{~cm} / \mathrm{hari})$ dan cepat terjadi proses penuaan sehingga kandungan serat kasar akan meningkat tajam dari $25 \%$ pada umur 20 hari menjadi $40 \%$ pada umur 120 hari (Kamlasi et al., 2014). Sementara itu, pemberian pupuk $\mathrm{N}$ dapat menstimulasi laju petumbuhan mencapai 2,93 $\mathrm{cm} /$ hari dan produksi biomasa mencapai 12 ton bahan kering/ha/tahun (Keraf et al., 2015). Namun, kandungan komponen serat terutama lignin, cukup tinggi $(7,51 \%)$ sehingga menurunkan daya cernanya apabila digunakan sebagai pakan dalam bentuk kering (Dami Dato, 1998). Salah satu teknik menurunkan kandungan karbohidrat struktural adalah hidrolisis menggunakan alkali alamiah seperti filtrat abu sekam padi (FASP) sehingga memutuskan ikatan lignin dengan selulosa dan hemiselulosa. Dami Dato dan Ghunu (2000) menggunakan konsentrasi FASP $15 \% \mathrm{~b} / \mathrm{v}$ dan proses dihidrolisis selama tiga jam pada substrat rumput Kume kering memberikan peningkatan dalam degradasi komponen serat (NDF, ADF, selulosa, hemiselulosa dan lignin), serta peningkatan kecernaan serat in vitro. Namun, hasil hidrolisis ini belum mampu meningkatkan nilai nutrisi substrat. Atas dasar tersebut, maka penelitian ini didesain untuk menguji efek kombinasi FASP, urea dan urease, di mana larutan urea berfungsi sebagai sumber nitrogen, sedangkan urease berfungsi sebagai katalis untuk hidrolisis urea menjadi ammonia sehingga kemungkinan turut 
meningkatkan hirolisis komponen serat dalam rumput Kume kering.

\section{MATERI DAN METODE}

Penelitian dilakukan di Laboratorium Ruminansia dan Analisa Proksimat BPT. Ciawi - Bogor, Indonesia. Substrat yang digunakan adalah rumput Kume kering (standing hay), isi rumen sapi segar sebagai sumber urease, urea, dan filtrat abu sekam padi (FASP) $15 \% \mathrm{~b} / \mathrm{v}$. Metoda eksperimen laboratorium menggunakan Rancangan Acak Lengkap (RAL) untuk menguji 6 perlakuan yang masing-masing diulang sebanyak 3 kali. Perlakuannya adalah: RK1= Rumput Kume kering dipercik FASP $15 \%$ b/v dihidrolisis selama 3 jam, RK2 $=\mathrm{RK} 1+$ urea $4 \%, \mathrm{RK}_{3}=\mathrm{RK} 1+$ urea $4 \%$ + urease $8 \%(1: 2), \mathrm{RK} 4=\mathrm{RK} 1+$ urea $4 \%+$ urease $12 \%(1: 3), \mathrm{RK}_{5}=\mathrm{RK} 1+$ urea $4 \%+$ urease $16 \%$ (1:4), dan RK6= RK1 + urea 4\% + urease 20\% (1:5). Pada setiap unit percobaan digunakan $1 \mathrm{~kg}$ rumput Kume kering sebagai substrat. Proses pembuatan FASP sesuai petunjuk Dami Dato (1998). Ke dalam satu liter FASP ditambahkan $40 \mathrm{~g}$ urea dan $10 \mathrm{~g}$ kalsium karbonat sebagai sumber kalsium, $18 \mathrm{~g}$ garam dapur sebagai sumber natrium, dan $2 \mathrm{~g}$ belerang sebagai sumber sulfur (Sutrisno, 1983). Prosedur hidrolisis dilakukan sesuai petunjuk Sutrisno et al. (1986). Lamanya hidrolisis adalah 3 jam, dihitung sejak mulut kantong plastik diikat. Setelah proses hidrolisis kantong plastik dibuka dan diukur $\mathrm{pH}-$ nya, diambil $200 \mathrm{~g}$ sebagai sampel, dikeringkan dan diproses untuk analisis laboratorium. Analisis di laboratorium terhadap komponen serat (NDF, selulosa, hemiselulosa, lignin) mengikuti petunjuk Van Soest (1977) serta Close dan Menke (1986).

Variabel yang diamati adalah, perubahan kandungan neutral detergent fibre (NDF), hemiselulosa, selulosa, lignin, dan acid detergent fibre (ADF). Data yang dikumpukan dianalisis secara statistik mengikuti proesdur general linear model untuk RAL dan perbedaan antar perlakuan dideteksi menggunakan prinsip Duncan. SPSS versi 23 dipakai sebagai alat bantu analisis.

\section{HASIL DAN PEMBAHASAN}

Rumput Kume kering yang telah dihidrolisis (RKKH) pada setiap perlakuan menunjukkan adanya penurunan kandungan NDF, selulosa, hemiselulosa, dan lignin, tetapi terjadi kenaikan komponen ADF (Tabel 1). Semakin tinggi rasio urea:urease, persentase penurunan kandungan NDF, selulosa, hemiselulosa, lignin semakin besar. Persentase penurunan terbesar tercatat pada perlakuan RK6 (rasio 1:5) dan terendah pada perlakuan yang tidak diberi tambahan urea dan urease (RK1). Hasil uji Duncan menunjukkan bahwa peningkatan rasio urea:urease diikuti dengan penurunan NDF, selulosa, hemiselulosa, dan lignin. Namun, efeknya tidak lagi terdeteksi secara statistik ketika rasio urea:urease dinaikan dari 1:4 ( $\left.\mathrm{RK}_{5}\right)$ ke 1:5 (RK6). Hal ini mengindikasikan bahwa rasio ureaurease 1:4 dan 1:5 memberikan respon yang sama besar, sehingga rasio 1:4 sudah cukup.

Tabel 1. Perubahan kandungan serat rumput Kume kering yang mengalami hidrolisis alkali menggunakan (FASP) saja (RK1), atau diberi tambahan urea sebesar 4\% (RK2), atau diberi tambahan urea sebesar $4 \%$ dan urease dengan rasio $1: 2$ $\left(\mathrm{RK}_{3}\right)$ atau 1:3 (RK4) atau 1:4 (RK5) atau 1:5 (RK6)

\begin{tabular}{|c|c|c|c|c|c|c|}
\hline \multirow{3}{*}{ Variabel } & \multicolumn{6}{|c|}{ Perlakuan } \\
\hline & RK1 & $\mathrm{RK} 2$ & $\mathrm{RK}_{3}$ & RK4 & $\mathrm{RK}_{5}$ & RK6 \\
\hline & \multicolumn{6}{|c|}{...................... } \\
\hline $\begin{array}{l}\text { Neutral } \\
\text { detergent } \\
\text { fibre }\end{array}$ & $-7,87^{a}$ & $-11,73^{b}$ & $-13,51^{c}$ & $-16,15^{d}$ & $-19,05^{\mathrm{e}}$ & $-19,49^{\mathrm{e}}$ \\
\hline $\begin{array}{l}\text { Hemiselu- } \\
\text { losa }\end{array}$ & $-31,10^{a}$ & $-42,04^{b}$ & $-47,79^{c}$ & $-55,61 d$ & $-64,41^{e}$ & $-65,72^{e}$ \\
\hline Selulosa & $-15,13^{a}$ & $-17,80^{b}$ & $-20,38^{c}$ & $-23,77^{d}$ & $-30,00^{e}$ & $-31,6 \mathrm{o}^{\mathrm{e}}$ \\
\hline Lignin & $-3,97^{\mathrm{a}}$ & $-6,67^{b}$ & $-12,18^{c}$ & $-17,49^{d}$ & $-19,86^{e}$ & $-20,16^{e}$ \\
\hline $\begin{array}{l}\text { Acid deter- } \\
\text { gent fibre }\end{array}$ & $8,84^{a}$ & $10,09^{b}$ & $11,16^{c}$ & $12,25^{\mathrm{d}}$ & $13,59^{\mathrm{e}}$ & $13,78^{\mathrm{e}}$ \\
\hline
\end{tabular}

\section{Kandungan NDF}

Penurunan kandungan NDF hasil penelitian ini berkisar 7,87-19,49\% lebih tinggi dari temuan Dami Dato (1998) sebesar 5,24-8,58\% dengan perlakuan FASP saja, juga lebih tinggi dari temuan Katipana et al. (2006) pada standing hay rumput Kume yang direndam cuka makan (konsentrasi 7,5\%). Penurunan NDF mungkin karena selama proses hidrolisis, urea melepaskan amonia, kemudian amonia membentuk amonium hidroksida yang bersifat alkali dapat memecahkan ikatan lignoselulosa (Van Soest, 1994).

Kedua jenis alkali (FASP dan urea-urease) dengan daya kerja optimum yang bersifat sinergi memecah lignoselulosa dalam substrat melalui proses hidrolisis yang berlangsung sempurna, dalam arti penambahan urea secara bersamaan dengan FASP yang diseimbangkan dengan urease membuat lebih banyak lagi ikatan lignoselulosa yang longgar dan/ atau putus dibanding hanya dihidrolisis dengan FASP sendiri. Fenomena ini mengakibatkan makin tinggi daya serap air ke dalam jaringan substrat, kelarutan nutrisi dan juga nilai kecernaan makin meningkat termasuk NDF. Hasil penelitian ini sejalan dengan yang dilaporkan oleh Kiangi et al. (1981) bahwa komponen serat dinding sel menurun dengan perlakuan amoniasi bila urease ditambahkan selama proses perlakuan. 


\section{Kandungan hemiselulosa}

Penurunan kandungan hemiselulosa hasil penelitian ini berkisar 31,10-65,72\% lebih tinggi dari yang diperoleh Dami Dato (1998) sebesar 19,60-31,77\% dengan perlakuan FASP saja. Keadaan ini wajar karena hemiselulosa mudah larut dalam air apalagi dengan pelarut alkali dan asam, dengan demikian seyogianya kandungannya menurun akibat perlakuan alkali FASP dan urea-urease. Penurunan kandungan hemiselulosa pada penelitian ini karena adanya sinergisme FASP dengan urea-urease memutuskan ikatan serat dalam jumlah besar sehingga sebagian besar rantai cabang hemiselulosa terputus, akhirnya hemiselulosa terlarut semakin meningkat (Dami Dato, 1998). Menurunnya kandungan hemiselulosa dimungkinkan karena tingkat percabangan rantai-rantai hemiselulosa beragam dan beberapa dari percabangan tersebut mudah larut (Chesson dan Forsberg,1988). Derajat kelarutan material dinding sel akan naik dengan semakin tingginya konsentrasi alkali (Jayasurya, 1979).

\section{Kandungan Selulosa}

Penurunan kandungan selulosa hasil penelitian ini berkisar 15,13-31,60\% lebih tinggi dari yang diperoleh Dami Dato (1998) yang hanya mencapai 1,42-5,74\% dengan perlakuan FASP saja. Keadaan ini dikarenakan selulosa sulit larut dalam air dibanding hemiselulosa (Sudradjat, 1979). Walaupun kandungan selulosa menurun tetapi persentasenya kecil dibanding hemiselulosa. Penurunan kandungan selulosa akibat perlakuan FASP mampu menghidrolisis atau merusak sebagian lignin dan hemiselulosa yang melindungi molekul selulosa, apalagi dibarengi dengan ureaurease secara bersinergi dan sekaligus memutuskan ikatan hidrogen baik ikatan inter maupun intra molekul selulosanya, sehingga selulosanya sendiri dirusak strukturnya. Dengan demikian, selulosa menjadi tidak terikat (bebas) dan strukturnya menjadi lunak dan mudah larut, akibatnya kandungan selulosa menurun.

Chesson dan Forsberg (1988) sependapat bahwa ikatan lignoselulosa lebih kuat dan selulosa itu sendiri merupakan homopolisakarida linier yang tidak bercabang, sehingga lebih sukar larut dibanding hemiselulosa. Ikatan hidrogen antar molekul selulosa yang sangat kuat tersebut hanya dapat hancur oleh asam dan basa kuat (Morrison, 1979). Pada penelitian ini, diakui bahwa aktivitas FASP dan urea sebagai alkali kuat tidak sebanding dengan aktivitas asam dan basa kuat sintetis, sehingga wajar bila penurunan kandungan selulosa lebih rendah dibanding hemiselulosa, tetapi harapannya minimal ikatan hidrogen dalam selulosa tersebut renggang.

\section{Kandungan Lignin}

Penurunan kandungan lignin hasil penelitian ini berkisar 3,97-20,16\% lebih tinggi dari hasil yang diperoleh Dami Dato (1998) yaitu mencapai 2,4020,28\% dengan perlakuan FASP saja. Perbedaan ini disebabkan adanya tambahan sinergi FASP, urea dan urease lebih efektif memutuskan ikatan lignoselulosa dibanding perlakuan Dami Dato (1998) yang hanya menggunakan FASP. Menurut Harkin (1973), ada tiga hal yang dilakukan alkali yakni: (1) membengkakkan serat; (2) memutuskan ikatan lignin karbohidrat yang labil terhadap alkali (benzil ester dan benzil eter yang bebas terhadap $p$-hidroksi yang dapat diubah menjadi quinon metida); dan (3) melarutkan beberapa fragmen lignin yang juga sama pada ikatan protein atau cynamat.

\section{Kandungan ADF}

Bertolak belakang dengan tiga komponen serat lainnya, kandungan $\mathrm{ADF}$ nyata meningkat seiring peningkatan urea:urease, tetapi tidak terdapat perbedaan antara rasio 1:4 (RK5) dan 1:5 (RK6). Peningkatan kandungan ADF hasil penelitian ini berkisar 8,84-13,78\% lebih tinggi dari yang diperoleh Dami Dato (1998) sebesar 5,04-9,37\% dengan perlakuan FASP saja. Ini membuktikan bahwa alkali alamiah FASP saja belum cukup untuk mengeksploitasi potensi rumput Kume kering sebagai pakan alternatif. Upaya pengolahan lanjutan oleh Ghunu et al. (2001) yang menambahkan urea-urease pada substrat dan lama pemeraman yang sama mendapatkan hasil yang kontradiktif dengan kedua hasil penelitian di atas, yakni dengan perlakuan FASP konsentrasi $15 \% \mathrm{~b} / \mathrm{v}$ bersamaan dengan $5 \%$ urea dan $10 \%$ urease dari kacang kedelai (rasio 1:2), kandungan ADF 55,03\%. Ketika level urea ditingkatkan menjadi 10 dan $15 \%$ dengan rasio yang sama (1:2), kandungan ADF menurun menjadi 52,30 dan 52,06\%, berarti terjadi penurunan sebesar 4,96 dan 5,40\%. Perbedaan-perbedaan ini disebabkan level dan rasio urea-urease, serta sumber urease eksogen. Aktivitas urease dari kacang kedelai lebih tinggi dibanding isi rumen, tetapi karena kacang kedelai adalah bahan pangan, maka alternatif menggantikannya dengan limbah RPH menjadi pilihan yang sangat ekonomis.

Hasil penelitian ini juga sejalan dengan Sudradjat (1979) yang mengemukakan bahwa selulosa merupakan komponen ADF yang sulit larut dalam air dibanding hemiselulosa, sehingga meningkatnya kandungan $\mathrm{ADF}$ setelah mengalami hidrolisis lebih diakibatkan oleh ikatan lignoselulosa banyak yang longgar dan/atau putus sehingga selulosa menjadi lebih banyak terdapat dalam bentuk bebas. Peningkatan kandungan ADF yang diperoleh pada penelitian ini juga kontradiktif dengan Khan et al. (1999) ketika urease yang bersumber dari tepung kacang kedelai dan tepung kacang buncis 
diberikan bersamaan dengan urea pada jerami padi efektif perubahannya menurunkan kandungan ADF. Kontradiksi ini lebih disebabkan oleh FASP yang pada penelitian ini berfungsi sebagai alkali telah bereaksi secara optimal pada konsentrasi $15 \% \mathrm{~b} / \mathrm{v}$ menyerang ikatan-ikatan serat substrat menyebabkan komponen ADF meningkat, sebaliknya komponen ADS (hemiselulosa terlarut) menurun.

\section{SIMPULAN}

Nilai manfaat rumput Kume kering dapat ditingkatkan dengan perlakuan hidrolisis alkali menggunakan FASP dan ditambahi urea dan enzim urease dengan rasio 1:4 merupakan perlakuan terbaik karena secara nyata menurunkan kanndungan serat dalam rumput Kume kering yakni lignin, hemiselulosa, dan selulosa.

\section{DAFTAR PUSTAKA}

Close, W. H., and K. H. Menke. 1986. Selected Tropics in Animal Nutrition. Manual Prepared for The $3^{\text {rd }}$ Hohenheim Course on Animal Nutrition in The Tropics and Semi-Tropics. $2^{\text {nd }}$ ed. Compiled by W. H. Close and K. H. Menke in Cooperation with H. Steingass and A. Troscher. Conducted by University of Hohenheim, Stuttgart, Federal Republic of Germany.

Chesson, A., and C. W. Forsbeg. 1988. Polysacharide Degradation by Rumen Microorganism. In: Hobson, P. N. (ed.). The Rumen Microbial Ecosystem. Elsevier App. Sci., New York. p. 7- 13 .

Dami Dato, T. O. 1998. PengolahanRumput Sorghum plumosum var. Timorense Kering Dengan Fitrat Abu Sekam Padi (FASP) terhadap Perubahan Komponen Serat dan Kecernaannya Secara in vitro. Tesis. Pascasarjana Universitas Padjajaran, Bandung.

Dami Dato T.O. dan S. Ghunu. 2000. Kandungan Komponen Serat, Kecernaan in vitro dan Nilai TDN Rumput Kume (Sorghum plumosum var. Timorense) Kering Hasil Hidrolisis Filtrat Abu Sekam Padi (FASP) Sebagai Sumber Alkali Alamiah. Laporan Penelitian. Fapet, Undana, Kupang.

Ghunu, S., T. O. Dami Dato, dan A. Aoetpah. 2001. Potensi Komponen Serat Rumput Kume Kering Hasil Hidrolisis Filtrat Abu Sekam Padi (FASP), Urea, dan Sumber Urease dari Kacang Kedelai Dilihat dari Kandungan dan Kecernaan in vitro. Laporan Penelitian. Politani, Kupang.

Harkin, J. M. 1973. Lignin.In: Butler, G. W., and R. W. Balley (eds.). Chemistry and Biochemistry of Herbage. Vol. I. Academyc Press, London and New York. p. 323-368.

Jayasurya, M. C. 1979. The Utilizations of Fibrous Residues in South Asia. Department of Animal Husbandry. Faculty of Agriculture, University of Paradenya, Paradenya, Sri Lanka.

Kamlasi, Y., M. L. Mullik dan T. O. Dami Dato. 2014. Pola Produksi dan Nutrisi Rumput Kume (Sorghum plumosum var. Timorense) Pada Lingkungan Alamiahnya. Jurnal Ilmu-Ilmu Peternakan24 (2): 31-40.

Katipana, N. G. F., D. Kana Hau., J. Nulik., J. I. Manafe, dan D. Amalo. 2006. Sifat Fisik dan Komposisi Kimia Standing Hay Rumput Kume yang Diolah dengan Cuka Makan dan Urea. Prosiding Seminar Nasional Komunikasi Hasil-hasil Penelitian Pertanian Bidang Tanaman Pangan, Perkebunan dan Peternakan Dalam Sistem Usahatani Lahan Kering. BBP2TP, Bogor. h. 376-382.

Keraf, F.K., J. Nulik, dan M. L. Mullik. 2015. Pengaruh Pemupukan Nitrogen dan Umur Tanaman Terhadap Produksi dan Kualitas Rumput Kume (Sorghum plumosum var. Timorense). Jurnal Peternakan Indonesia. 17(2):123-130.

Khan, M. J., J. R. Scaife, and F. D. Hovell. 1999. The Effect of Different Sources of Urease Enzyme on The Nutritive Value of Wheat Straw Treated withUrea as a Source of Ammonia. Asian-Aust. J. Anim. Sci. 12: 1063-1069.

Morrison, I. M. 1979. The Degradation and Utilization of Straw in The Rumen. In: Grossbard (ed.). Proceeding of a Symposium on Straw Decay and Workshop on Assessment Techniques. Held at Hatfield Polytechnic: Straw Decay and Its Effect on Disposal and Utilization. John Wiley and Sons, New York. p. 237-244.

Sudradjat. 1979. Kimia Kayu. Departemen Teknologi Hasil Pertanian. Fateta, IPB, Bogor

Sutrisno, C. I. 1983. Pengaruh Minyak Nabati dalam Mengatasi Defisiensi Zn Pada Sapi yang Memperoleh Ransum Berbahan Dasar Jerami Padi. Disertasi. Program Pascasarjana, IPB, Bogor.

Sutrisno, C.I., H. S. Soelistyono, dan W. Slamet. 1986. Potensi Kualitatif dan Kuantitatif Makanan Ternak Ruminansia Besar Dalam Kaitannya Dengan Efisiensi Usaha Ternak. Dalam: MUKERNAS - III PPSKI, Salatiga.

Van Soest, P.J. 1977. Plant Fiber and Its Role in Herbivora Nutrition. The Cornell Veterinarian, 67(3): 307-326.

Van Soest, 1994. Nutritional Ecology of the Ruminant: Ruminant Metabolism, Nutritional Strategies, The Cellulolytic Fermentation and The Chemistry of Forages and Plant Fibers. O\&B Books, Inc., Corvallis, Oregon, USA. 